\title{
PENGARUH LATIHAN KOORDINASI MATA KAKI DAN KELINCAHAN TERHADAP KEMAMPUAN DRIBBLING
}

\author{
Muhammad Razif ${ }^{1}$, Romi Mardela ${ }^{2}$, Afrizal $S^{3}$, Hendri Irawadi ${ }^{4}$ \\ ${ }^{1234}$ Fakultas Ilmu Keolahragaan, Universitas Negeri Padang, Indonesia
}

\section{Informasi Artikel}

Diterima 2020-11-23

Direvisi 2021-02-02

Dipublikasikan 2021-04-19

\section{Keyword:}

Foot Coordination Exercise, Agility, ability Dribbling

\begin{abstract}
The problem in this research is that theability Dribbling of SSB Putra Wijaya Padang players is still not good. This research is to improve theability Dribbling through ankle coordination training and the agility of SSB Putra Wijaya Padang players. The purpose of this study was to determine the effect of ankle coordination training and agility on theability Dribbling at SSB Putra Wijaya Padang. This type of research is a quasi-experimental. This research was conducted in August - September 2020 at the Kompi A football field, Lapai, Padang City. The population in this study were all SSB Putra Wijaya Padang players totaling 83 people. The sample collection technique in this study was purposive sampling, so the sample in this study U-17 years amounted to 19 people. The instrument in this study was to use thetest Dribbling zigzag. The data analysis technique used in this study was the $t$ test statistical analysis technique. Based on data analysis using t-test statistics, the results of this study indicate the effect of ankle coordination training and agility on theability dribbling of SSB Putra Wijaya players $(7,4>1,734)$. Obtained an average value of the pre-test $=20.63$ and the average value of the post-test $=19.89$.
\end{abstract}

(C) 2020 The Authors. Published by Universitas Negeri Padang.

This is an open access article under the CC BY-NC-SA license (https://creativecommons.org/licenses/by-nc-sa/4.0/

\section{Penulis Korespondensi:}

Muhammmad Razif

Universitas Negeri Padang

Email:, muhammadrazif2406@gmail.com,

\section{PENDAHULUAN}

Olahraga ialah aktivitas yang harus dilakukan secara rutin dan berkesinambungan yang gunanya untuk meningkatkan peforma dalam kehidupan sehari-hari (Haryanto \& Welis, 2019. Olahraga juga merupakan suatu kegiatan fisik yang berkembang pesat dan disukai banyak kalangan masyarakat didunia dan digemari oleh semua lapisan masyarakat dari anak-anak sampai orang dewasa, laki-laki maupun perempuan, sampai masyarakat pelosok-pelosok desa (Barlian, 2020). Kegiatan olahraga banyak faktor pendukung yang mempengaruhi untuk mendapatkan prestasi, seperti:kondisi fisik, teknik, taktik, dan mental (Soniawan \& Irawan, 2018). Salah satunya yaitu cabang olahraga sepakbola. Olahraga sepakbola salah satu olahraga paling popular didunia, ini adalah olahraga kontak dan tantangan kebugaran fisik dengan membutuhkan berbagai keterampilan dalam intesitas yang berbeda (Cloak R dkk, 2014).

Sepakbola adalah salah satu olahraga didunia yang telah popular dan disukai banyak kalangan masyarakat. Permainan ini sudah sangat berkembang dan digemari oleh semua lapisan masyarakat dari anak-anak sampai orang dewasa, laki-laki maupun perempuan, masyarakat 
sampai masyarakat pelosok-pelosok desa. Hal ini terbukti dengan banyak berdirinya sekolah sepakbola (SSB) yang tersebar di seluruh penjuru pelosok negeri dengan berbagai bentuk yang diharapkan.

Menurut (Syukur \& Soniawan, 2015) Sepakbola merupakan permainan yang membutuhkan banyak energi, kepintaran di dalam lapangan memacu semangat, sekaligus memberikan kegembiraan melalui kebersamaan dalam sebuah tim. Dalam olahraga sepakbola disamping memiliki teknik, taktik, dan mental yang baik juga diperlukan penguasaan kondisi fisik yang baik pada atletnya (Syukur \& Soniawan, 2015). Sepak bola modern membutuhkan tingkat ketahanan, kecepatan, kekuatan dan keterampilan koordinasi yang tinggi.

Perkembangan olahraga sepakbola juga didukung sepenuhnya oleh pemerintah dan masyarakat. Hal ini terbukti dengan diadakannya kejuaran-kejuaraan, baik tingkat daerah maupun ditingkat nasional secera berjenjang dan berkelanjutan. Sebagaimana dijelaskan dalam UndangUndang Republik Indonesia No 3 tahun 2005 Pasal 3 Ayat 4 tentang Sistem Keolahragaan Nasional yang menyatakan bahwa, "Pembinaan dan pengembangan olahraga prestasi dilaksanakan dengan memberdayakan perkumpulan olahraga, menumbuh kembangkan sentra pembinaan olahraga yang bersifat nasional dan daerah, dan menyelenggarakan kompetisi secara berjenjang dan berkelanjutan". Oleh karena itu, pemain harus memiliki kebugaran fisik yang berkembang dengan baik (Modric dkk, 2020). Arne Pettersen (2015:1) menyatakan sepakbola adalah salah satu olahraga paling populer di kalangan generasi muda di seluruh dunia, dengan peningkatan jumlah anak muda dan pemain wanita.

Dalam upaya peningkatan prestasi para pemain sepakbola. Latihan adalah salah satu faktor yang sangat menentukan dalam pencapaian prestasi. Bentuk latihan yang dipilih juga akan sangat menentukan dalam mencapai target latihan yang diinginkan (Wiratama, 2019). Prestasi terbaik atau biasa disebut prestasi puncak dalam pembinaan olahraga diperlukan suatu proses persiapan yang terencana secara bertahap, terarah, sistimatis, dan berkelanjutan dengan kata lain bahwa proses persiapan dimaksud mencakup seluruh proses yang dimulai dari penyusunan program latihan, implementasi, program di lapangan dan sampai kepada evaluasi program latihan secara bertahap sesuai dengan tujuan yang ingin dicapai (Arwandi \& Ardianda, 2018). Untuk mewujudkan tercapainya prestasi yang tinggi dalam sepakbola, pembinaan harus dimulai dari usia dini agar dapat membuahkan hasil yang optimal. Pembinaan dilakukan untuk melahirkan bibit-bibit muda sebagai regenerasi bangsa untuk cabang sepakbola, (Marta \& Oktarifaldi, 2020).

Dribbling merupakan salah satu teknik dalam permainan sepakbola yang sangat penting dan harus dikuasai oleh pemain bola sepakbola. Dribbling ialah teknik menggulirkan bola atau memindahkan bola dari satu tempat ke tempat lain dengan menggunakan kaki sambil berlari (Basrizal dkk, 2020). Fetri dan Donie (2019) mengatakan "dribbling merupakan salah satu teknik sepakbola yang memerlukan koordinasi mata kaki yang bagus dan kelincahan yang bagus dengan menjaga keseimbangan tubuh tetap pada titik tumpu ketika adanya hadangan dari lawan.

Upaya meningkatkan keterampilan dribbling tersebut tentunya melalui model latihan yang sangat efektif dengan memperhatikan berbagai faktor yang berpengaruh terhadap dribbling bola sepakbola (Akmal \& Lesmana, 2019). Adapun beberapa faktor lain yang mempengaruhi kemampuan dribbling adalah faktor internal dan eksternal. Faktor internal dapat disebabkan karena kemampuan fisik, taknik, taktik dan kemampuan mental atlet. Sedangkan faktor eksternal dapat disebabkan seperti, sarana dan prasarana pendukung latihan, Kamampuan pelatih baik yang berupa pengetahuan, kompetisi, dan faktor kondisi alam (Naldi \& Irawan, 2020).

Dalam melakukan dribbling pada sepakbola ditunjang oleh kemampuan kelincahan yang dimiliki oleh setiap pemain. Kelincahan mempunyai kedudukan dan peran dalam melihat respon jalannya bola, untuk melakukan gerakan dengan bola yang tepat dan dapat dribbling bola dengan baik sehingga lawan yang berusaha untuk merebut bola bisa dihindari (Wardani \& Irawadi, 2020). Kelincahan ialah kemampuan pemain untuk bergerak kekiri, kekanan, kedepan dan juga berputar untuk melindungi bola dari lawan dan tidak kehilangan keseimbangan. Kedua tim selain penjaga gawang, bertarung satu sama lain untuk merebut bola ke gawang lawan. Sepak bola sangat tinggi menuntut permainan dimana para peserta berada mengalami berbagai tindakan yang membutuhkan keseluruhan kekuatan dan produksi tenaga, kecepatan, kelincahan, keseimbangan, stabilitas, fleksibilitas, dan yang memadai tingkat ketahanan (Mario Jovanovic, et al. 2011). 
Selanjutnya dalam melakukan dribbling sepakbola koordinasi mata kaki juga diperlukan dimana hal ini mensinkronisasikan antara posisi bola, lawan untuk mengarahkan bola. Koordinasi pada prinsipnya merupakan pengaturan syaraf-syaraf pusat dan tepi secara harmonis dalam menggabungkan gerakan-gerakan otot synergis dan antagonis secara selaras. Koordinasi merupakan kemampuan seseorang untuk merangkaikan beberapa gerakan menjadi satu pola gerakan yang efektif dan efisien. Berkaitan dengan koordinasi Irawadi (2014:181) menyatakan bahwa, "Koordinasi merupakan keterpaduan dari beberapa gerakan yang dilakukan secara bersamaan. Koordinasi yang dimaksud disini akan melahirkan efisiensi dari sebuah gerakan yang akan meningkatkan kecerdasan dari seseorang dan melahirkan gerak otomatis".

Koordinasi dibedakan atas beberapa jenis. Menurut Bompa dalam Irawadi (2018:163) mengklarifikasikan koordinasi atas dua jenis yaitu: (1) koordinasi umum, (2) koordinasi khusus (spesifik).

1. Koordinasi umum

Koordinasi umum adalah koordinasi sebagai basis untuk mengembangkan koordinasi spesifik. Koordinasi disini lebih banyak dalam bentuk gerakan umum dan belum menggunakan alat lain atau berbentuk gerak kecabangan olahraga tertentu.

2. Koordinasi khusus (spesifik)

Koordinasi khusus (spesifik) adalah koordinasi motorik yang berhubungan erat dengan keterampilan-keterampilan gerak tertentu. Koordinasi lebih cendrung kepada koordinasi gerak keterampilan pada cabang-cabang olahraga tertentu. Kadang-kadang gerakan disini menuntut koordinasi yang lebih rumit menggunakan alat untuk melakukan keterampilan tersebut.

Koordinasi yang buruk akan membuat gerakan menjadi tidak sinkron dimana arah bola yang tidak sesuai dengan apa yang seharusnya diharapkan (Sakti, 2017). Menurut Harsono (1988:221) menyatakan bahwa "Kecepatan, kekuatan, daya tahan, kelentukan, kinestetik, sense, balance, dan ritme, memberikan kesinambungan dan keterpaduan di dalam koordinasi gerak, oleh karena itu satu sama lainnya mempunyai hubungan yang erat". Apabila salah satu unsur tidak ada atau kurang berkembang, maka hal ini berpengaruh terhadap kesempurnaan koordinasi. sehingga dapat diambil suatu kesimpulan bahwa dribbling adalah suatu kemampuan menguasai bola dengan kaki oleh pemain sambil berlari untuk melewati lawan atau membuka daerah pertahanan lawan.

Kegunaan menggiring bola sangat besar untuk membantu penyerangan untuk menembus pertahanan lawan. dribbling berguna untuk mengontrol bola dan menguasainya sampai seorang rekan satu tim bebas dan memberikannya dalam posisi yang lebih baik. dan dapat juga disimpulkan bahwa Dari uraian di atas koordinasi mata kaki dalam hal ini dapat dijadikan sebagai aktualisasi dari seluruh komponen gerak yang terlibat dan bekerja secara bersamaan untuk mengatasi berbagai kesulitan secara cepat, tepat dan efisien. Sehubungan dengan ini, sumbangan koordinasi mata kaki terhadap penguasaan pergerakan yang dapat mengkoordinasikan seluruh rangkaian gerakan dribbling melalui gerakan yang cepat dan efisien akan meningkatkan kualitas dribbling pada permainan sepakbola.

Kelincahan merupakan beberapa unsur kondisi fisik. Unsur yang di maksud adalah kecepatan, unusr kekuatan, dan unsur kelentukan yang tergambar dalam bentuk gerak yang terorganisasi dengan baik. Unsur kecepatan dibutuhkan untuk bergerak cepat dari satu titik ke titik yang lain. Unsur kekuatan dan kelentukan dibutuhkan saat proses awal berpindah tubuh. Saat proses perpindahan dibutuhkan kekuatan menumpu atau menolakkan kaki, dan kelentukan dibutuhkan untuk meliukkan atau memindahkan bagian tubuh mengarah pada gerakan selanjutnya.

Menurut hidayat (2014:61) kelincahan adalah kemampuan seseorang untuk dapat mngubah arah dengan cepat dan tepat pada waktu bergerak tanpa kehilangan keseimbangan. Kelincahan ini berkaitan dengan kecepatan dan kelentukan. Tanpa unsur keduanya baik, seseorang tidak dapat bergerak dengan lincah. Selain itu, faktor keseimbangan juga sangat berpengaruh terhadap kemampuan kelincahan seseorang.

Kemampuan bergerak atau berpindah tempat (mengatur posisi tubuh) sangat tergantung pada kemampuan kaki. Artinya semakin baik atau semakin cepat pergerakkan kaki seseorang, 
maka semakin mudah iya berpindah posisi. Oleh sebab itu kelincahan sangat identik dengan kemampuan kerja kaki footwork) Irawadi (2013:108).

Efendi, A.R , Rovi. P. \& Zainal. A. (2018) Mengatakan "kelincahan yang baik akan dapat menyesuaikan diri dengan pergerakan bola yang selalu berubah ketika si pemain kehilangan bola, maka dengan kemampuan dan kelincahannya, lebih memungkinkan baginya untuk mendapat bola itu kembali, tentu saja dengan usaha dan latihan yang keras.Karena pentingnya unsur kelincahan dalam permainan sepakbola khususnya dalam menggiring bola, maka perlu mendapat porsi dan perhatian khusus dari pelatih ataupun pembina tim sepakbola".

Berdasarkan uraian diatas, pada hakekatnya kelincahan merupakan seluruh daya dan upaya pemain dalam berlari menyerahkan seluruh tubuh untuk melakukan gerakan dengan arah yang berubah-ubah secara cepat dengan waktu yang singkat. Seseorang pemain yang mempunyai aglity yang baik akan mampu melakukan gerakan dengan efektif dan efisien.

SSB Putra Wijaya Padang merupakan salah satu klub sepakbola yang dibina oleh pelatih yang bernama Uthan Hal Hakim S,E yang berlatih di lapangan Kompi A, Lapai, Kec. Nanggalo, kota padang. SSB Putra Wijaya Padang memiliki 73 orang yang terdaftar sebagai pemain, pemain yang terdaftar tersebut merupakan gabungan dari beberapa kelompok umur yang ada di SSB Putra Wijaya Padang yaitu: U-9 berjumlah 20 orang, U-12 tahun berjumlah 20 orang, U-14 tahun berjumlah 14 orang, U-17 berjumlah 19. Latihan dilaksanakan setiap hari Selasa, Rabu, Jumat, dan Minggu dimulai dari pukul 15.00 WIB sampai selesai.

Berdasarkan wawancara dengan pelatih SSB Putra Wijaya Padang, bahwasanya masih banyak kelemahan pada pemain SSB Putra Wijaya salah satunya dribbling. Pada saat pengamatan dan observasi yang telah dilakukan peneliti pada tanggal 29 Juli 2020, pada saat itu SSB Putra Wijaya Padang melakukan latihan, peneliti melihat juga kemampuan dribbling yang dimiliki oleh pemain SSB Putra Wijaya Padang masih kurang baik. Contohnya dari saat melewati lawan pemain tersebut kewalahan saat melakukan dribbling.Adapun dribbling yang dilakukan pemain pada saat melewati lawan, bola yang di kuasi oleh pemain tersebut menjauh dan keseimbangan permain tersebut pun tidak stabil. Adapun yang menjadi salah satu permasalahan yang dimiliki oleh pemain SSB Putra Wijaya Padang yang peneliti lihat adalah dimana pada saat melakukan dribbling melewati lawan pemain sering kali tidak berhasil. Sehingga dribbling menjadi sia-sia dan mudah dirampas oleh lawan. Berdasarkan keterangan di atas, menjadi acuan bagi peneliti bahwa kemampuan dribbling SSB Putra Wijaya Padang masih kurang baik. seorang pemain sepak bola harus menguasai teknik dribbling bagus, karena dribbling memungkinkan pemain untuk menciptakan ruang, mengontrol bola, dan mengoper pemain lawan (Danny Mielke, 2007).

\section{METODE}

Jenis penelitian ini eksperimen semu.Populasi dalam penelitian ini adalah seluruh pemain SSB Putra Wijaya Padang yang berjumlah 73 orang. Teknik pengambilan sampel dengan purposive sampling dengan sampel yaitu U-17 tahun yang berjumlah 19 orang dan sampel yang saya teliti 19 orang. Instrument penelitian dilakukan dengan cara tes kemampuan dribbling. Data dianalisis dengan uji statistic beda rerata hitung ( $t$-test) dengan $\alpha=0,05$.

\section{HASIL DAN PEMBAHASAN}

1. Deskripsi Penelitian Data

a. Pengaruh Latihan Koordinasi Mata Kaki Dan Kelincahan Terhadap Kemampuan Dribbling Pemain SSB Putra Wijaya Padang

Berdasarkan hasil pre-test dari 19 sampel penelitian yang diperoleh melalui instrument tes zig-zag dribbling di SSB Putra Wijaya Padang di peroleh nilai tercepat 19,02 nilai terlambat 22,64 rata-ratanya 20,63 dan standar deviasinya 0,97. Dari hasil pos-test setelah diberikan perlakuan selama 16 kali pertemuan diperoleh nilai tercepat 18,03 , nilai terlambat 21,88 , rata-ratanya 19,89 dan standar deviasinya 0,93 .

Tabel 1. Distribusi Frekuensi Hasil Data Pre-Test dan Post-Tets kemampuan Dribbling Pemain SSB Putra Wijaya Padang 


\begin{tabular}{|c|c|c|c|c|c|c|c|}
\hline \multirow[t]{2}{*}{ No } & \multirow[t]{2}{*}{$\begin{array}{c}\text { Kelas } \\
\text { Interval }\end{array}$} & \multicolumn{2}{|c|}{$\begin{array}{c}\text { Frekuensi Pre } \\
\text { Test }\end{array}$} & \multirow{2}{*}{$\begin{array}{c}\text { Kelas } \\
\text { Interval }\end{array}$} & \multicolumn{2}{|c|}{$\begin{array}{c}\text { Frekuensi Post } \\
\text { Test }\end{array}$} & \multirow[t]{2}{*}{ Kriteria } \\
\hline & & $\mathrm{Fa}$ & Fr (\%) & & $\mathrm{Fa}$ & Fr (\%) & \\
\hline 1 & $<18,99$ & 0 & 0 & $<18,99$ & 4 & 21 & Baik Sekali \\
\hline 2 & $19,00-21,00$ & 13 & 68 & $19,00-21,00$ & 14 & 74 & Baik \\
\hline 3 & $21,01-23,00$ & 6 & 32 & $21,01-23,00$ & 1 & 5 & Sedang \\
\hline 4 & $23,01-25,00$ & 0 & 0 & $23,01-25,00$ & 0 & 0 & Cukup \\
\hline 5 & $>25,01$ & 0 & 0 & $>25,01$ & 0 & 0 & Kurang \\
\hline & Jumlah & 19 & $100 \%$ & & 19 & $100 \%$ & \\
\hline
\end{tabular}

Berpedoman pada tabel, dapat dilihat hasil analisis data pre-test tidak ada kategori baik sekali, kategori baik sebanyak 13 orang (68\%), kategori sedang sebanyak 6 0rang (32\%), tidak ada pemain dengan kategori kurang dan kategori kurang sekali. Sedangkan hasil post-test orang dengan kategori baik sekali sebanyak 4 orang (21\%), kategori baik sebanyak 14 orang (74\%), kategori sedang sebanyak 1 orang (5\%), tidak ada pemain yang memiliki kategori kurang, dan kategori kurang sekali. Berdasarkan tabel yang ditampilkan jelas terdapat peningkatan kemampuan Dribbling di SSB Putra Wijaya Padang.

1. Uji Normalitas

Hipotesis penelitian ini diuji dengan melakukan analisis t-test, sebelum melakukan analisist-test, terlebih dahulu dilakukan uji normalitas untuk mengetahui apakah data berasal dari yang berdistribusi normal atau tidak dengan menggunakan uji Lilliefors dengan taraf singnifikan $\alpha=0,05$

Tabel 2. Hasil Uji Normalitas Peningkatan Kemampuan Dribbling di SSB Putra Wijaya Padang U-

\begin{tabular}{|l|l|l|l|}
\hline \multicolumn{1}{|c|}{17.} \\
\hline Kelompok & $\mathrm{L}_{\text {hitung }}$ & $\mathrm{L}_{\text {table }}$ & Keterangan \\
\hline Pre test & 0.14042 & \multirow{2}{*}{0,195} & \multirow{2}{*}{ Normal } \\
\hline Post test & 0.16431 & & \\
\hline
\end{tabular}

Berdasarkan uji normalitas penelitian didapat harga $\mathrm{L}_{\text {hitung }}$ yang diperoleh lebih kecil dari $\mathrm{L}_{\text {tabel. }}$. Dengan demikian dapat disimpulkan bahwa semua kelompok data pada penelitian ini diambil dari populasi yang berdistribusi normal, sehingga dapat digunakan untuk pengujian hipotesis.

3 Uji Hipotesis

Tabel 5. Hasil Pengujian Hipotesis

\begin{tabular}{|l|l|l|l|l|l|l|}
\hline $\begin{array}{c}\text { Bentuk } \\
\text { Latihan }\end{array}$ & Mean & \multicolumn{1}{|c|}{$\mathrm{Sd}$} & $\mathrm{t}_{\text {hitung }}$ & $\mathrm{t}_{\text {tabel }}$ & Hasil uji & Keterangan \\
\hline Pre test & 20,63 & 0,97 & 7,4 & 1,734 & Signifikan & Ha diterima \\
\hline Post test & 19,89 & 0,93 & & & \\
\hline
\end{tabular}

Hipotesis yang akan diujikan dalam penelitian ini adalah latihan koordinasi mata kaki dan kelincahan memberikan pengaruh yang berarti terhadap kemampuan dribbling pemain SSB Putra Wijaya Padang. Berdasarkan hasil pengukuran kemampuan dribbling pemain SSB Putra Wijaya Padang dengan skor rata-rata 20,63 dan standar deviasi 0,97 pada pre test, dan setelah diberi perlakuan sebanyak 16 kali skor rata-rata 19,89, dan standar deviasi 0,93 pada post test. 
Berdasarkan pada tabel 5 dapat dilihat bahwa terdapat pengaruh latihan koordinasi mata kaki dan kelincahan terhadap kemampuan dribbling pemain SSB Putra Wijaya Padang $\left(\mathrm{t}_{\text {hitung }}=7,4>\right.$ $t_{\text {tabel }}=1,734$ ), dengan demikian hipotesis yang diajukan diterima.

\section{Pembahasan}

Pembahasan hasil penelitian ini dimaksudkan sebagai gambaran untuk mempermudah menarik kesimpulan penelitian. Dalam pengujian hipotesis diketahui bahwa terdapat pengaruh yang signifikan antara pre test dan post test terhadap kemampuan dribbling pemain SSB Putra Wijaya Padang. Sebelum diberikan perlakukan terhadap sampel terlebih dahulu dilakukan pre test. Berdasarkan hasil tes tersebut ternyata kemampuan dribbling pemain SSB Putra Wijaya Padang diperoleh rata-rata pada saat pre test yaitu sebesar 20,63. Namun setelah diberi perlakukan selama 16 kali pertemuan maka terjadi peningkatan dengan rata-rata pada saat post test 19,89 pemain SSB Putra Wijaya Padang. Dengan hasil penelitian ini dapat disimpulkan bahwa latihan koordinasi mata kaki dan kelincahan berpengaruh terhadap kemampuan dribbling pemain SSB Putra Wijaya Padang. Hal ini diperkuat setelah dilakukan uji t, dimana diperoleh hasil thitung sebesar 7,4 yang lebih besar dari tabel dalam taraf $\alpha=0,05$ sebesar 1,734 .

Berdasarkan kajian teori, ditemukan hasil penelitian terdahulu yang relevan dan berhubungan pada penelitian ini yang berjudulPengaruh Koordinasi Mata-Kaki Kelincahan Dan Kecepatan Dengan Kemampuan Menggiring Bola Pada Permainan Sepakbola Pada Siswa Sma Negeri 11 Makassar,penelitian ini termasuk penelitian deskriptif,populasi penelitian ini adalah berjumlah 100 siswa kelas XI SMA Negeri 11 Makassar Sampel penelitian 40 Siswa SMA Negeri 11 Makassar. Teknik analisis data yang digunakan adalah teknik korelasi dan regresi dengan menggunakan SPSS Versi 20.00 pada taraf signifikan 95\% atau 0,05.Hasil penelitian menunjukan pada masing-masing struktur bahwa, 1) ada pengaruh langsung koordinasi mata kaki dengan kemanpuan menggiring bola dalam permainan sepak bola pada siswa SMA Negeri 11 makassar,dengan nilai koefisien jalur sebesar 0,412 dan $(\mathrm{P}<0.05), 2)$ ada pengaruh langsung kelincahan dan dengan kemanpuan menggiring bola dalam permainan sepakbola pada siswa SMA Negeri 11 Makassar, dengan koefisien jalur sebesar 0,337 dan $(\mathrm{P}<0.05) .3$ ) ada pengaruh langsung kecepatan dengan kemanpuan menggiring bola dalam permainan sepakbola pada siswa SMA Negeri 11 Makassar, dengan koefisien jalur sebesar 0,314 dan $(\mathrm{P}<0.05) .4)$ ada pengaruh koordinasi mata kaki melalui kecepatan dengan kemanpuan menggiring bola pada permainan sepakbola pada siswa SMA Negeri 11 Makassar,dengan koefisien jalur sebesar 0,500 dan ( $\mathrm{P}<0.05), 5)$ ada pengaruh kelincahan melalui kecepatan dengan kemampuan menggiring bola pada permainan sepakbola siswa SMA Negeri 11 Makassar, dengan koefisien jalur sebesar 0,287 dan $(P<0.05), 6)$ ada pengaaruh yang tidak signifikan antara koordinasi mata kaki melalui kelincahan dengan kemanpuan menggiring bola dengan pengaruh langsung lebih besar dibanding pengaruh tidak langsung sebesar $0,138,7$ ) ada pengaruh tidak langsung kelincahan melalui koordinasi mata kaki dengan kemanpuan menggiring bola dengan pengaruh langsung lebih besar dibanding pengaruh tidak langsung sebesar 0,09.

Dribbling merupakan mengolah bola yang digerakkan terhadap salah satu kaki dari satu tempat ke tempat yang lain terhadap tetap dalam penguasaan. Dribbling juga merupakan suatu kemampuan menguasai bola dengan kaki oleh pemain sambil berlari untuk melewati lawan atau membuka daerah pertahanan lawan (Budiman \& Sin, 2019). Dribbling banyak hal dapat mempengaruhi seperti pengalaman bermain yang dimiliki, semakin lama seseorang berlatih maka kemampuannya akan semakin baik (Pratama dkk, 2020). Menggiring bola bisa dilakukan dengan menggunakan kaki bagian dalam dan kaki bagian luar, oleh karena itu terdapat banyak kombinasi (Gardasevic \& Bjelica, 2014). Kegunaan menggiring bola sangat besar untuk membantu penyerangan untuk menembus pertahanan lawan. dribbling berguna untuk mengontrol bola dan menguasainya sampai seorang rekan satu tim bebas dan memberikannya dalam posisi yang lebih baik. Dimana hal ini juga harus didasari dengan latihan yang teratur sesuai dengan program yang terbentuk (Ridwan \& Irawan, 2018).

Sardar (2014) menyatakan "gerakan dribbling terdiri dari beberapa gerakan yaitu gerakan merubah arah, dan gerakan melindungi bola yang didukung komponen biomotor antara lain kelincahan dan kelentukan (flexibility)". Didalam cabang olaraga permainan sepakbola, kelincahan atau ketangkasan yang diatas rata-rata bisa meberikan kemudahan penguasaan teknik bermain, efisien dan efektif di dalam penggunaan tenaga pada saat melakukan 
$\overline{\text { dribbling. Kelincahan adalah latihan yang berintensitas tinggi yang dilakukan dengan waktu yang }}$ cepat tanpa kehilangan keseimbangan (Hakim, 2018).

Terjadinya peningkatan keterampilan dribbling bermain sepakbola ini berkemungkinan disebabkan oleh adaptasi latihan fisik (Ridwan, 2020). Sebagai mana telah dikemukakan pada kajian teori sebelumnya latihan kelincahan adalah bentuk latihan kelincahan yang dilakukan dengan berbelok-belok dengan melewati tonggak atau cone yang telah disiapkan. Tujuan latihan kelincahan adalah untuk melatih kemampuan berubah arah dengan cepat dan tepat tanpa kehilangan keseimbangan. Sehingga dari latihan yang diberikan dapat mempengaruhi keterampilan dribbling pemain sepakbola (Afrizal, 2003).

Selain itu dengan komponen koordinasi mata-kaki, seorang pemain sepakbola akan dapat melakukan menggiring bola dengan baik dan cepat, karena pemain tersebut akan dapat menggabungkan beberapa elemen gerak menggiring bola menjadi satu pola gerak menggiring bola yang halus, efisien dan harmonis (Supriadi, 2015). Dengan melakukan latihan koordinasi mata kaki dan kelincahan secara teratur sesuai dengan program latihan yang telah dirancang dengan baik dan disesuaikan maka dapat meningkatkan kemampuan dribbling pemain sepakbola. Berdasarkan hasil penelitian tersebut maka dapat disimpulkan bahwa terdapat pengaruh latihan koordinasi mata kaki dan kelincahan terhadap kemampuan dribbling pemain SSB Putra Wijaya Padang. Jadi untuk meraih prestasi terbaik, seorang perlu melalui suatu proses latihan yang panjang secara terprogram, sistematis, terarah dan berkesinambungan sesuai dengan olahraganya. Proses latihan merupakan rangkaian kegiatan fisik dan psikis (mental) yang dilakukan oleh atlet di bawah bimbingan pelatih untuk tujuan meningkatkan dan mempertahankan prestasi atlet (Mardela, 2020).

\section{KESIMPULAN}

Berdasarkan analisis data dan pembahasan, maka dapat dikemukan kesimpulan bahwa: "latihan koordinasi mata kaki dan kelincahan terdapatnya pengaruh yang berarti terhadap kemampuan dribbling", maka dengan demikian terdapat pengaruh latihan koordinasi mata kaki dan kelincahan terhadap kemampuan dribbling pemain SSB Putra Wijaya U-17. Maka disarankan kepada penulis selanjutnya agar lebih mengembangkan bentuk-bentuk latihan koordinasi mata kaki dan kelincahan terhadap dribbling dalam sepakbola supaya lebih banyak lagi variasi dalam melakukan latihan.

DAFTAR PUSTAKA

Afrizal, S. (2003). Kontribusi Hasil latihan Kelincahan dan Kelentukan terhadap Hasil Belajar Sepakbola. Buletin Pembelajaran, JurnalPatriot (1), 28-39.

Akmal, I., \& Lesmana, H. S. (2019). Kontribusi Kecepatan dan Kelincahan Terhadap Kemampuan Dribbling Pada Pemain SSB POSS. Jurnal Patriot, 2(5), 1197-1210.

Arwandi, J., \& Ardianda, E. (2018).Latihan Zig-Zag Run Dan Latihan Shuttle Run Berpengaruh Terhadap Kemampuan Dribbling Sepakbola. Performa, 3(01), 32-32.

Barlian, E. (2020). Pengaruh Latihan Jump To Box Terhadap Kemampuan Heading. Performa, 5(1), 101-109.

Basrizal, R., Sin, T. H., Irawan, R., \& Soniawan, V. (2020). Latihan Kelincahan Terhadap Peningkatan Kemampuan Dribbling Pemain Sepakbola. Jurnal Patriot, 2(3), 769-781.

Budiman, A., \& Sin, T. H. (2019). Pengaruh Latihan Kecepatandan Latihan Kelincahan Terhadap Keterampilan Dribbling Pemain Sepakbola SSB Putra Wijaya. Jurnal JPDO, 2(1), 177-181.

Cania, A., \& Alnedral, A. (2019). Tinjauan Kondisi Fisik Atlet Atletik Jarak Menengah Unit Kegiatan Universitas Negeri Padang. Jurnal JPDO, 2(1), 192-197. Retrieved from http://jpdo.ppj.unp.ac.id/index.php/jpdo/article/view/217 
Cloak, R., Nevill, A., Smith, J., \& Wyon, M. (2014). The acute effects of vibration stimulus following FIFA $11+$ on agility and reactive strength in collegiate soccerplayers. Journal of Sport and Health Science, 3(4), 293-298.

Efendi,A.R., Rovi. P.\&, Zainal. A. 2018. Pengaruh Latihan Kelincahan Terhadap Kemampuan Menggiring Dalam Permainan Sepakbola Mahasiswa Ukm Sepakbola Ikip Pgri Pontianak Jurnal Pendidikan Olahraga, Vol. 7, No. 1, Juni 2018

Fetri, F., \& Donie. (2019). Latihan Kelincahan Berpengaruh Terhadap Kemampuan Dribbling Sepakbola. Jurnal Patriot, 2(5), 1169-1178.

Gardasevic, J., \& Bjelica, D. 2014. The Effects Of The Training In The Preparation Period On The Dribbling Speed With Fifteen Year Old Football Player. Sport Month, (40-42), 160-166.

Gunnar, Mathisen dan Pettersen Arne, 2015. "The Effect of Speed Training on Sprint and Agility Performance In Famale Youth Soccer Players".Journal of Physical Education and Sport, 15(3): 395-399.

Harsono, Coaching dan Aspek-Aspek Psikologis Dalam Coaching, Jakarta : Tambak Kussuma, 1988.

Haryanto, J., \&Welis, W. (2019). Exercising Interest in the Middle Age Group. Jurnal Performa Olahraga, 4(02), 214-223.

Irawadi, Hendri. 2018. Kondisi Fisik dan Pengukuran. Padang: Fakultas Ilmu Keolahragaan Universitas Negeri Padang

Mardela, R. (2020). Pengaruh Passing Group Terhadap Passing Pemain Sepakbola SMAN 4 SUMBAR FA Kelompok Usia 15-17 Tahun. Jurnal Patriot, 2(1), 182-192.

Marta, I. A., \& Oktarifaldi, O. (2020). Koordinasi Mata-Kaki dan Kelincahan terhadap Kemampuan Dribbling Sepakbola. Gelanggang Olahraga: Jurnal Pendidikan Jasmani Dan Olahraga, 4(1), 1-14.

Modrik, Toni, dkk. 2020. Aerobic fitness and game performance indicators in professional football players; playing position specifics and associations. a Faculty of Kinesiology, University of Split, Split, Croatia.

Mario, J., Sporis G., Omrcen D., Fiorentini, F. (2011). Effects of Speed, Agility, Quickness Training Method on Power Performance in Elite Soccer Players. Journal of Strength and Conditioning Research, 25(5), 85-92

Naldi, I. Y., \& Irawan, R. (2020). Kontribusi Kemampuan Motorik Terhadap Kemampuan Teknik Dasar Pada Atlet SSB (Sekolah Sepakbola) Balai Baru Kota Padang. Performa, 5(1), 9-16.

Nurwahidin,Hakim. (2018). Pengaruh Kelincahan, Kecepatan Lari Dan Koordinasi Mata-Kaki Terhadap Kemampuan Menggiring Bola Pada Permainan Sepakbola Siswa Smpn 4 Takalar.

Pratama, M., Alnedral, A., Sin, T., \& Soniawan, V. (2020). Metode Circuit Training Berpengaruh Terhadap Kemampuan Dribbling Sepakbola. Jurnal Patriot, 2(3), 874-884.

Ridwan, M., \& Irawan, R. (2018). Validitas Dan Reliabilitas Tes Kondisi Fisik Atlet Sekolah Sepakbola (Ssb) Kota Padang "Battery Test Of Physical Conditioning". Performa, 3(02), 90-90.

Ridwan, M. (2020). Kondisi Fisik Pemain Sekolah Sepakbola (SSB) Kota Padang. 
Performa, 5(1), 92-100.

Sardar, Biswajit. (2014). Effect of Warm-up of DifferentDuration on Selected Soccer Skill Performance.International Journal of Advanced Research. Issue2 (9).

Sakti, B. P. I. (2017). Hubungan Koordinasi Mata-Kaki Dan Kelincahan Dengan Keterampilan Menggiring Bola Dalam Permainan Sepakbola Pada Siswa Ekstrakurikuler Sma Negeri 2 Lubuklinggau. Biormatika: Jurnal IImiah Fakultas Keguruan Dan IImu Pendidikan, 3(02).

Supriadi, A. (2015). Hubungan Koordinasi Mata-Kaki Terhadap Keterampilan Menggiring Bola Pada Permainan Sepakbola. Jurnal IImu Keolahragaan, 14(1), 1-14.

Soniawan, V., \& Irawan, R. (2018). Metode Bermain Berpengaruh Terhadap Kemampuan Long Passing Sepakbola. Performa Olahraga, 3(01), 42-42.

Syukur, A., \& Soniawan, V. (2015).The Effects Of Training Methods And Achievement Motivation Toward Of Football Passing Skills.Jipes-Journal Of Indonesian Physical Education And Sport, 1(2), 73-84.

Wardani, A. S. P., \& Irawadi, H. (2020). Perbedaan Pengaruh Latihan Kelincahan Shuttle Run dengan Latihan Lateral Run terhadap Kemampuan Menggiring Bola Siswa U-14 Ssb Putra Wijaya Fc Padang. Jurnal Patriot, 3(1), 62-72.

Wiratama, P. (2019). Soccer Coaching. Performa Olahraga, 4(02), 101-110. 